
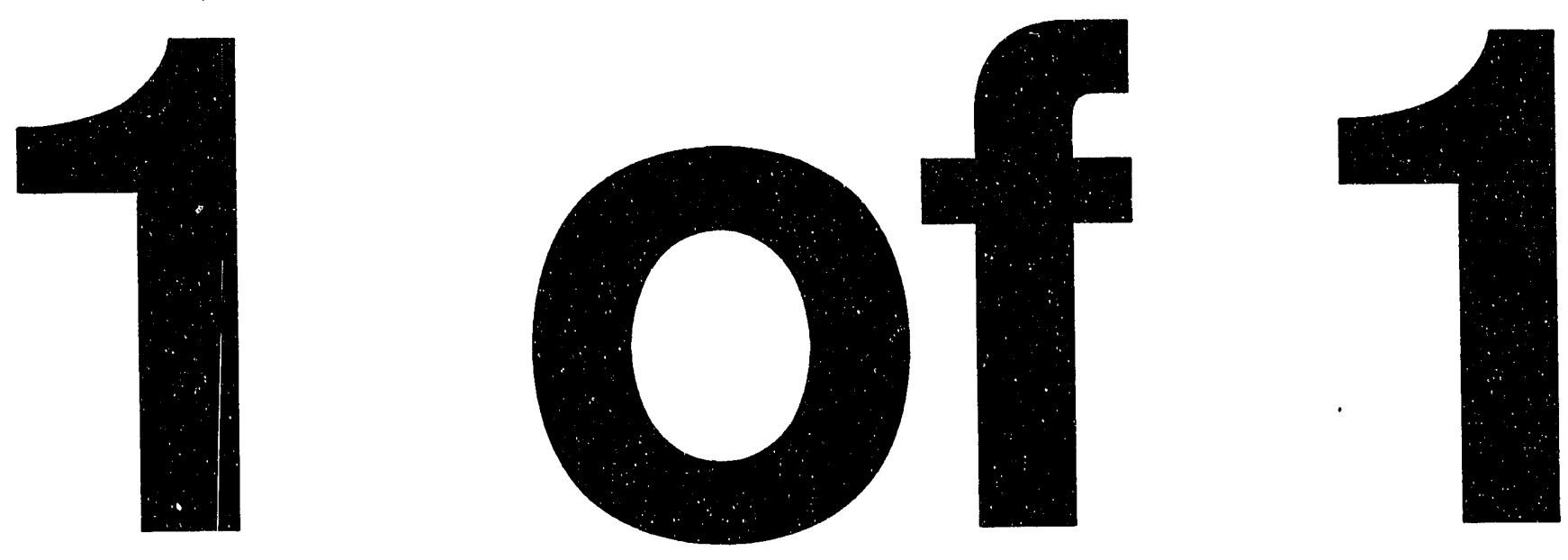


\section{RADIOLYTIC HYDROGEN PRODUCTYON FROM PROCESS VESSELS IN HB LINE - PRODUCTION RATES COMPARED TO EVOLUTION RATES AND DISCUSSION OF LASL REVIEWS (U)}

by N. E. Bibler

Westinghouse Savannah River Company

Savannah River Site

Aiken, South Carolina 29808

Other Authors:

\section{RECEIVED JUN O 91993 OSTI}

This paper was prepared in connection with work done under Contract No. DE-AC09-89SA18035 with the U. S. Department of Energy. By acceptance of this paper, the publisher and/or recipient acknowledges the U. S. Government's right to retain a nonexclusive, royalty-free license in and to any copyright covering this paper, along with the right to reproduce and to authorize others to reproduce all or part of the copyrighted paper.

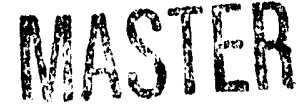




\section{DISCLAIMER}

This report was prepared as an account of work sponsored by an agency of the United States Government. Neither the United States Government nor any agency thereof, nor any of their employees, makes any warranty, express or implied, or assumes any legal liability or responsibility for the accuracy, completeness, or usefulness of any information, apparatus. product, or process disclosed, or represents that its use would not infringe privately owned rights. Reference herein to any specific commercial product, process, or service by trade name, trademark, manufacturer, or otherwise does not necessarily constitute or imply its endorsement, recommendation, or favoring by the United States Government or any agency thereof. The views and opinions of authors expressed herein do not necessarily state or reflect those of the United States Government or any agency thereof.

This report has been reproduced directly from the best available copy.

Available to DOE and DOE contractors from the Office of Scientific and Technical Information, P.O. Box 62, Oak Kidge, TN 37831; prices available from (615) 576-8401, FTS 626-8401.

Available to the public from the National Technical Information Service, U.S. Department of Commerce, 5285 Port Royal Rd., Springfield, VA 22161. 
Keywords: Radiolysis, Hydrogen production, Nitric acid, Pu-238, HB-Line

Retention Period: Permanent

CC R. T. BEGLEY, 773-A

W. H. BRITTON, 703-A

L. PAPOUCHADO, 773-A

E. W. HOLTZSCHEITER, 773-AM.

A. L. BLANCETT, 773-A

M. J. PLODINEC, 773-A
P. W. DICKSON, 703-E

O. M. EBRALIMA, 703-E

H. C. WOLF, 221-HBL

E. DELGENIO, $992 \mathrm{~W}-1$

E. A. KYSER, 773-A

DC \& RM, 773-52A (4)

NOVEMBER 12,1992

TO: R. MARER

FROM: N. E. BIBLER

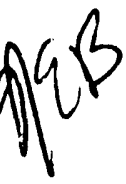

RADIOLYTIC HYDROGEN PRODUCTION. FROM PROCESS VESSELS IN AB IINE PRODUCTION RATES COMPARED TO EVOLUTION RATES AND DISCUSSION OF IASI REVIEWS

\section{INTRODUCTION AND SUMMABY}

Hydrogen production from radiolysis of aqueous solutions can create a safety hazard since hydrogen is flammable. At times this production can be significant, especially in $\mathrm{HB}$ line where nitric acid solutions containing high concentrations of $\mathrm{Pu}-238$, an intense alpha emitter, are processed. The hydrogen production rates from these solutions are necessary for safety analyses of these process systems. In 1974 I measured hydrogen production rates from alpha radiolysis of nitric acid solutions using Cm-244 as the source of the alpha particles (1). Recently there has been some discussion concerning whether my rates are applicable for the safety analyses or whether results from tests with Pu-239 $(2,3)$ should be used. The tests with Pu-239 measured the rates of gas evolution from nitric acid solutions and my tests measured maximum hydrogen production rates. To gain further information on this subject, scientists at Los Alamos Scientific Laboratory (LASI) were asked to compare my results to the results with Pu-239. This memorandum compares my measured production rates with the measured evolved hydrogen rates. The results of the reviews by two scientists at LASL are also presented and discussed. Based on analysis of produced versus evolved hydrogen rates, I recommend that the production rates that I measured be used in safety analyses. The reviewers at LASL are in complete agreement with this recommendation. 


\section{HYDROGEN PRODUCTION RATES COMPABSD TO FVOIUTION RATES}

Figures 1 and 2 show the results of all the experiments measuring hydrogen rates from alpha radiolysis of nitric acid solutions. A literature search performed this week indicated no work had been done in this field since mine in $1974(1)$. The rates in Eigures 1 and 2 are presented as molecules of hydrogen measured per $100 \mathrm{eV}$ of alpha energy absorbed by the solution. This quantity is called the G-value for hydrogen, $G\left(\mathrm{H}_{2}\right)$. With this value and knowing the concentration of alpha emitters in solution, the rate of hydrogen formation can be calculated. Figure 1 shows measured G-values for tests where efforts were taken to ensure that all of the hydrogen gas that was produced was removed from the nitric acid solution and measured. Reference 1 used $\mathrm{Cm}-244$ (an intense alpha emitter with $t_{1 / 2}=17.9$ years) as the source of the alpha particles. The solution was agitated to ensure that all the gas was removed from solution. The volume of gas produced as a function of time or alpha dose was measured. The composition of the gas was also measured. Figure 1 also shows the results of studies where Po-210 $\left(t_{1 / 2}=0.38\right.$ years) was used as the source of the alpha particles (4). In these tests, the solutions were pumped on after various times to ensure that all the gas was removed from the solutions. The amount of gas obtained was measured and its composition determined. Note in Figure 1 that the results with Cm-244 and Po-210 are in excellent agreement. The data in Figure 1 indicate that $\mathrm{G}\left(\mathrm{H}_{2}\right)$ decreases as the nitrate concentration increases. This is due to the fact that nitrate ions can successfully compete for $H$ atoms formed by the radiation. These $\mathrm{H}$ atoms are the precursors of the hydrogen (5). The appropriate chemical reactions are:

$$
\mathrm{H}+\mathrm{H} \longrightarrow \mathrm{H}_{2} \text { and } \mathrm{H}+\mathrm{NO}_{3}^{-} \rightarrow \mathrm{NO}_{2}+\mathrm{OH}^{-}
$$

Figure 2 compares the data from Eigure 1 with data from tests where only the gas evolved from solution was measured. These data are presented on a logarithmic rather than a linear scale to more clearly illustrate the differences in the data at large nitrate concentrations. In tests where only the evolved gas was measured (References 2 and 3 ), the solutions were not agitated or pumped on. They were simply stored at ambient temperature for a period of time and the pressure above the solution measured as a function of alpha dose. The results of two non agitated tests with

$\mathrm{Cm}-244$ (1) are also presented in Figure 2. In these two tests the volume of gas evolving from a non agitated solution was measured. Note in Eigure 2 that the values for G(H2) are lower in all cases where the hydrogen rates were measured based on gas removed from solution. In the tests where all the gas that was produced was measured, these rates are the maximum hydrogen production rates. The rates at which hydrogen is released from the solution are dependent on various factors such as the agitation of the 


\section{SAVANNAR RIVER TECHNOLOGY CENTER}

solution, the solubility of hydrogen in the solution, and even the shape of the vessel. With regard to agitation, consider the amount of gas released from a bottle of coca cola that has been shaken compared to one that has not been shaken. Concerning the shape of the vessel, consider gas escaping from a solution stored in a wide tank to one stored in a pipe where the liquid-gas interface is less. When these factors are considered, it is apparent that it is difficult to reliably predict how fast a radiolytically produced gas escapes from a solution without performing tests on the solution in the actual tank in which it will be stored. Consequently, when performing a safety analysis it is best to use the maximum rate of hydrogen production. This is known only when all the hydrogen produced is measured. As indicated in the next section, the reviewers at LASL agree with this.

\section{IASI BHYTEKS OF RADTOTYTIC PRODUCTION OF HYDROGFN}

At the request of Mr. Victor Stello, Jr., Principal Deputy Assistant Secretary for Facilities of the U. S. Department of Energy, the papers reporting my work with $\mathrm{Cm}-244$ (1) and Sheppard's work with Pu-239 (2) were sent to Dr. D. R. Harbur at LASL for review. Mr. Stello wanted IASL to review the works and offer an opinion concerning which rates of hydrogen production should be used for safety calculations at SRS - mine or Sheppard's. At Li:SL the works were reviewed by Dr. S. F. Marsh and Dr. K. K. S. Pillay. A copy of each of these reviews is attached. I've also attached a copy of a letter that Dr. Harbur sent to $\mathrm{Mr}$. Stello summarizing the reviews. All three scientists at LASL recommend that my values for the rates of hydrogen production be used for safety analyses and not the values measured by Sheppard. The rates of hydrogen production that I measured are the maximum rates at which hydrogen can be released from solution. Even though the reviewers agree that my values should be used, I have one major problem with their reviews. I think both reviewers place too much emphasis on the role of $\mathrm{Pu}$ in influencing the chemistry that is occurring during radiolysis. In my study I did two experiments with $0.21 \mathrm{M}$ Pu present as well as the $\mathrm{Cm}-244$ (1). These tests were at 5.6 and $10 \mathrm{M}$ nitric acid. The results agreed well with results in absence of $\mathrm{Pu}$ suggesting that $\mathrm{Pu}$ was not affecting the rate of hydrogen production. Eurther, it appears that Marsh has misinterpreted my results when he states that my results agree with Sheppard's (and Kazanjian's) when Pu is present. For example, at $10 \mathrm{M}$ acid I found that $\mathrm{G}\left(\mathrm{H}_{2}\right)$ is 0.1 , while the other workers found values approximately $4 \mathrm{x}$ less. To me a factor of four indicates disagreement. However, this disagreement does not affect the conclusion that my G-values should be used for safety analysis calculations. 


\section{RETERENCES}

1. N. E. Bibler, "Curium-244 Alpha Radiolysis of Nitric Acid, Oxygen Production from Direct Radiolysis of Nitrate Ions," J. Rhys. Chem 78 (3) pp. 211-214 (1974).

2. J. C. Sheppard, "Alpha Radiolysis of Plutonium (IV)Nitric Acid Solutions," Pacific Northwest Laboratory Report BNWL-751 (May 1968).

3. Y. I. Savel'ev, A. V. Ershova, and M. V. Vladimirova, "Alpha-Radiolysis of Aqueous Solutions of Nitric Acid," Badiokhim, $2(2)$ pp. 225-230 (1966).

4. A. R. Kazanjian and D. R. Horrell, "Radiolytically Generated Gases in Plutonium-Nitric Acid Solutions," Radiat. Effects 13, pp. 277-280 (1972).

5. I. G. Dranganic and Z. D. Dranganic, The Radiation Chemistry of Water, p. 76, Academic Press, NY (1971). 


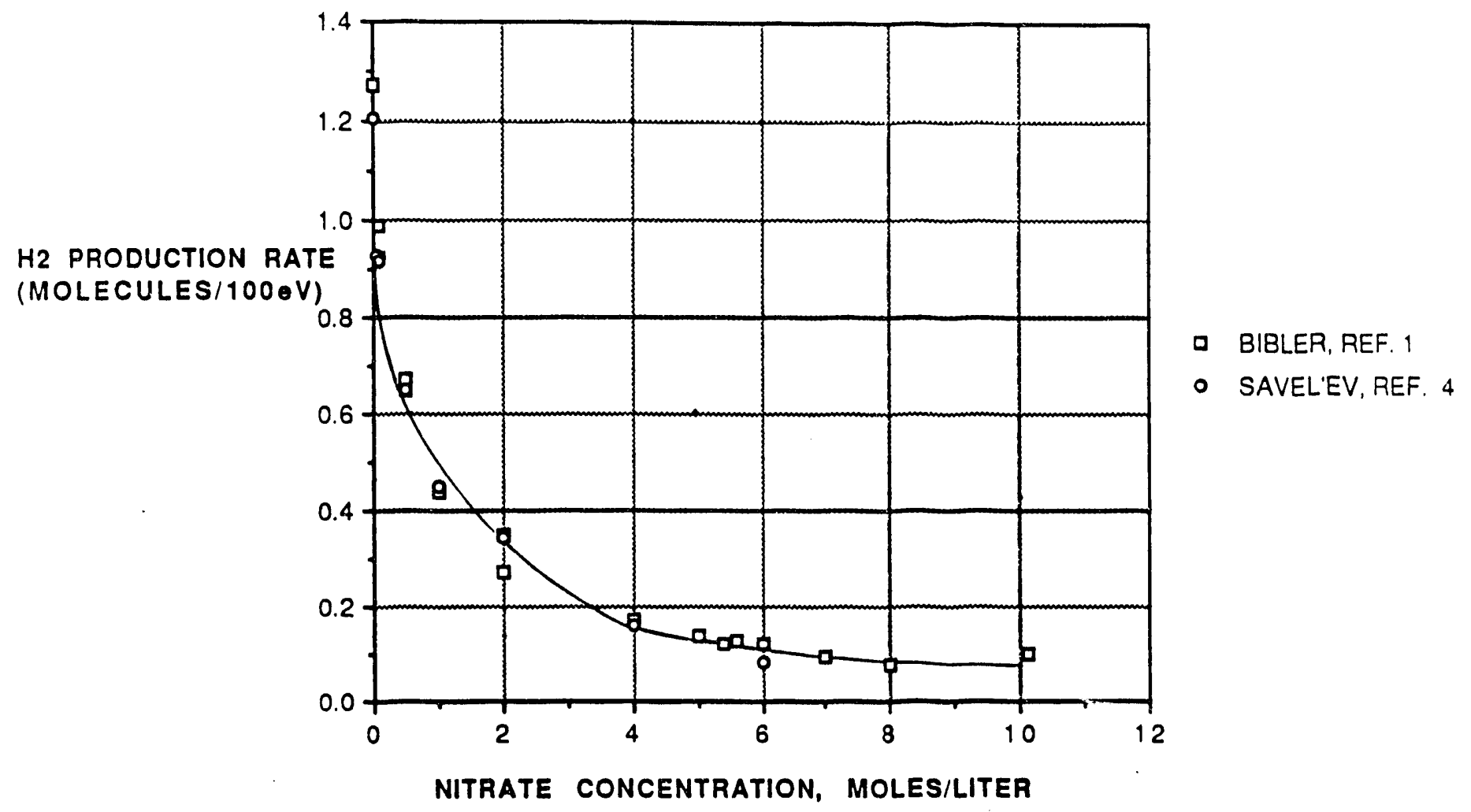

Figure 1. Hydrogen production rate from alpha radiolysis of nitric acid solutions. $\mathrm{Cm}-244$ was used as the alpha source in Reference 1 . Po-210 was used in Reference 4. 


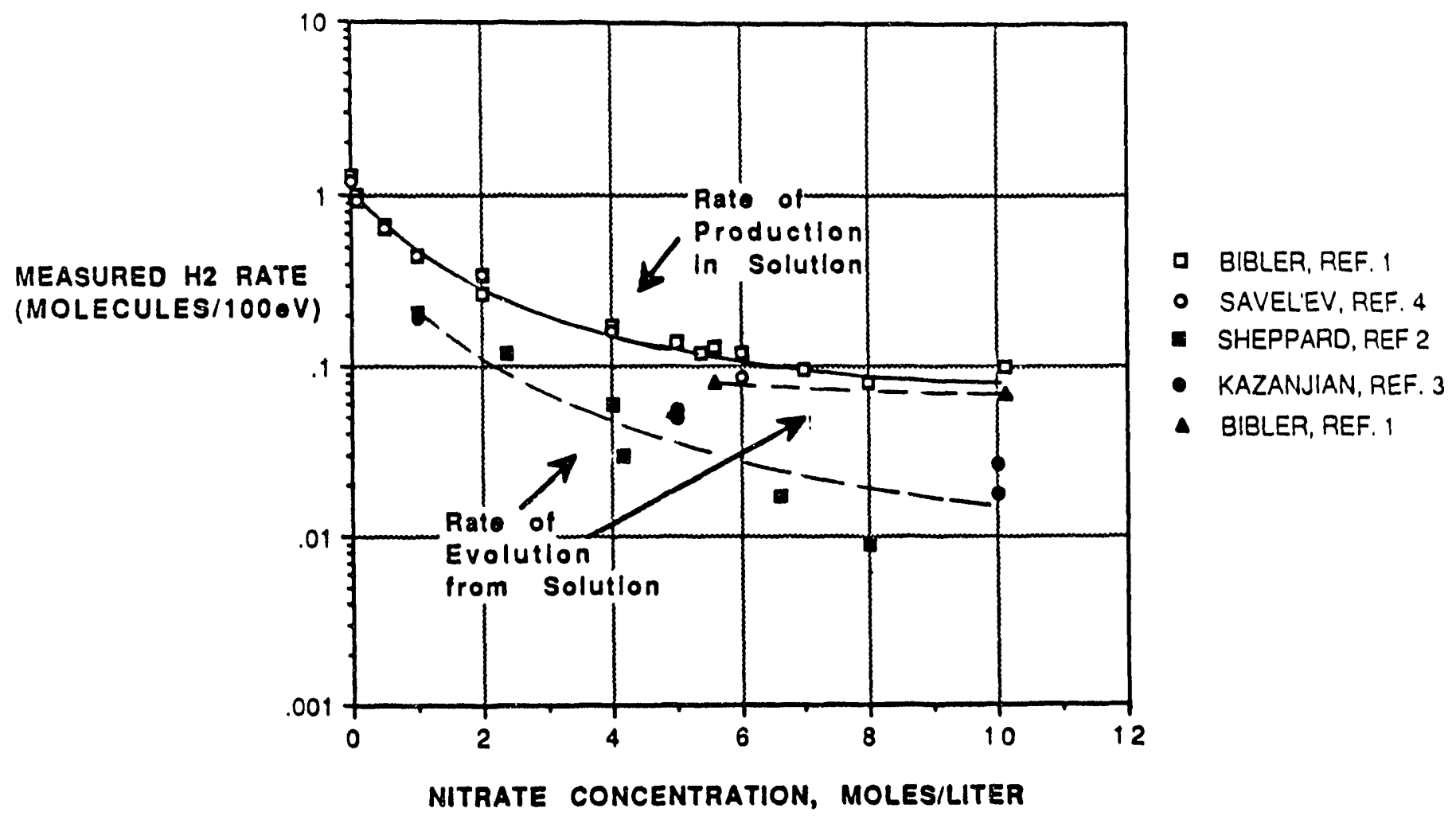

Figure 2. Measured bydrogen rates from alpha radiolysis of nitric acld solut 10ns. The open symbols and solid ino define data from test: where all the gas that was produced was measured. The solld symbols and dashed Iines are for tests where only the evolved gas was measured. 
LOS AlamoS

Los Alamos National Laboratory

Los Alamos, New Mexico 87545

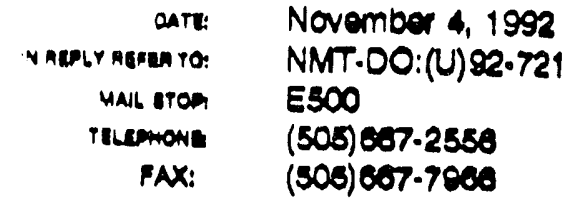

Victor Stello, Jr.

Principal Doputy Assistant

Secrotany for Facilitice

U.S. Department of Energy

FORS/DP-6/4A-043

1000 Independence Ave., S.W.

Weshington, DC 20385

Dear Mr. Sterio: Vic

\section{SUBJECT: HYDROGEN GAS BUILDUP IN SAVANNAH RIVER PROCESS VESSELS}

In revlowing the documents from Savannah Rlver sent to us yesterday, we agree with their calculations concerning hydrogen gas generation in the October 12 , 1992, momo. This memo uses the $\mathrm{G}\left(\mathrm{H}_{2}\right)$ from Sheppards work. While I belleve there are several valid reasons for explaining why Bibler's $\mathrm{G}\left(\mathrm{H}_{2}\right.$ ) values are higher (some of whlch are articulated in the attached reviow by Fred Mareh), I would tend to agree that the higher values should be used for saioty analysis calculations. With enough supporting ovidence, it might be poseible to argue that hydrogen generation and ultimate hydrogen ges bulldup in the vapor phase are very different for a particular vesest, but that evidence does not yot exist. Further, it would appear that the difference between hydrogen generation and ultimate hydrogen gas bulldup would be dependent upon multiple variables.

There are several mothods such as purging or catalyole that could miligate the isk posed by this potential hazard and I belleve that they noed to be considered.

\section{Sincerely,}<smiles>C[C@H]1C[C@@H]2CCC[C@H]1CC2</smiles>

Dolbert R. Harbur

Divialon Leader

Nuclear Materide Teohnology

DRH:enw

Attach. Dlat. on page 2. 


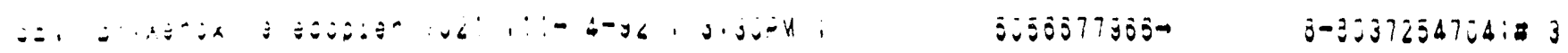

NMT.DO:(U) P.721

Novomber 4, 1002

Harbur to Stallo

Attach.: 1) Memo dated 11/4/92, Marsh to Harbur, same sub).

2) FAX dated 11/4/92, Pillay to Harbur

xc: $\quad$ CRM-4, MS A150

E. M. Wowerka, ADCM, MS A102

D. R. Harbur, NMT-DO, MS E500

NMT.DO file

bcc: N. Biblor, WH-SPC (FAX "1803-725-4704) 
To: D. R. Herbur, NMT Divirion Leader, MS Es00

From: S. F. Marah, NMT-2, MS EsO1

Subject: Hydrc zen Ges Buildup in Savannah River Process Vessele

I have reviewed the documents FAXed to you by Chuck Meson and have also attempted to quickly review other published material that might be pertinent.

$\mathrm{G}\left(\mathrm{H}_{2}\right)$ values are highest in pure water and decreage with increasing altric acid concentration. This effect is attributed to the reaction of altrate iop with atomic hydrogen radicale before they can form moleculer bydrogen. Iroa is known to have similar effect. It would not surprise the if plutonium, which can have sigaificant amounts of (III), (IV), and (VI) oxidation stater simultingeously existing in acid solution, could elso affeet $\mathrm{G}\left(\mathrm{H}_{2}\right)$. Although $\mathrm{Kazanjin} \mathrm{n}^{2}$ studied the effect of two high concentrations of plutonium ( 50 and $100 \mathrm{~g} / \mathrm{L}$ ), I find no investigation of the of fect of much lower levels of a high-upeciflconetivity isotope, such as $238 \mathrm{Pu}$. The posibillity of chemical reactloas ghat involve plutonium should be considered. The $G\left(\mathrm{H}_{2}\right)$ values of Bibler, ${ }^{3}$ Sheppard, ${ }^{4}$ and Karajojian, all of whom had epprocieble plutonium in solution, are in reasosable agreemest (with the exceptiog of Bibler's value for statio $10.1 \mathrm{M}$ acid). However, Savel'ev, ${ }^{3}$ who used 210 po alpha source in plutosium-free solutions, reports sorewhat higher $G\left(h_{2}\right)$ values.

Some literature values for $\mathrm{G}\left(\mathrm{H}_{2}\right)$ from alphe radiolysis are:

\begin{tabular}{|c|c|c|c|}
\hline Nirrie Acid Molneity & Pus/L & $\mathrm{GH}_{22}$ & Beference \\
\hline $\begin{array}{l}5.6 \text { (agitated) } \\
5.6 \text { (static) } \\
10.1 \text { (agitated) } \\
10.1 \text { (static) }\end{array}$ & $\begin{array}{l}\text { so } \\
\text { so } \\
\text { so } \\
50\end{array}$ & $\begin{array}{l}0.13 \\
0.08 \\
0.10 \\
0.07\end{array}$ & $\begin{array}{l}\text { Bibler } \\
\text { Bibler } \\
\text { Bibler } \\
\text { Bibler }\end{array}$ \\
\hline $\begin{array}{l}1.0 \\
2.4 \\
4.2 \\
6.6 \\
8.0\end{array}$ & $\begin{array}{r}58 \\
117 \\
112 \\
113 \\
112\end{array}$ & $\begin{array}{l}0.28 \\
0.13 \\
0.059 \\
0.057 \\
0.024\end{array}$ & $\begin{array}{l}\text { Shepperd } \\
\text { Sheppard } \\
\text { Sheppard } \\
\text { Sheppard } \\
\text { Sheppard }\end{array}$ \\
\hline $\begin{array}{l}0.1 \\
1.0 \\
5.0\end{array}$ & $?$ & $\begin{array}{l}0.5 \\
0.18 \\
0.05\end{array}$ & $\begin{array}{l}\text { Bakh } \\
\text { Bakh } \\
\text { Bakh }\end{array}$ \\
\hline $\begin{array}{r}1 \\
1 \\
3 \\
5 \\
10 \\
10\end{array}$ & $\begin{array}{r}50 \\
100 \\
50 \\
100 \\
50 \\
100\end{array}$ & $\begin{array}{l}0.20 \\
0.19 \\
0.056 \\
0.050 \\
0.018 \\
0.027\end{array}$ & $\begin{array}{l}\text { Kazanjian } \\
\text { Kazanjian } \\
\text { Kazanjian } \\
\text { Kazanjian } \\
\text { Kazanjian } \\
\text { Kazanjian }\end{array}$ \\
\hline
\end{tabular}




0.01
0.05
0.1
0.5
1.0
2.0
4.0
6.0

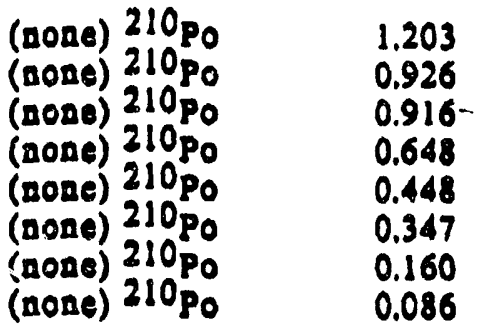

Savel'er Sevel'er Sevel'ev Surel'er Savel'ev Savel'ev Sevel'er Savel'er

\section{Commerto}

1. Observed differences in $G\left(H_{2}\right)$ valuee might reflect a contribution from the multiple oxidacion atates (and disproportionation) of plutonium. The higher $\mathrm{G}\left(\mathrm{H}_{2}\right)$ values of Savel'er, who used polonium at the alpha source in the abseace of plutoajum, aupports this posaibility.

2. Bibler reported higher $\mathrm{G}\left(\mathrm{H}_{2}\right)$ values when the solutions were agltated. Agitation would be expected to eweep out the molecular bydrogea gas before it could renct with solution componeats, and also give less opportunity for intermediate rediolytic specios to recombine. Biblez's findings sugsest that agitation should be avoided durins procensiag, if possible.

3. Plutonium is knowa to disproportionate móre resdily at lower concentrations of nitric acid. Radiolytic hydrosen peroxide then reoxidizes Pu(III) to (IV), which again dieproportionates to Pu(III) and (VI). Perbeps this also pleys a role. in side-reactiona that decrease the formation of molecular hydrogen.

4. Sheppard temonstrated that a palladium catalyst is very effective in preventing the buildup of radiolytic gates, and even causer already existins ges pressure to decrease when palledium ls added. Aa sppropriate quantity of this catalyot could be available to expose to the vapor phase if hydrogen inereases above a specified limit. Shepperd found that the palladium catelyat kept ass precsure down for nearly a month, which provides a long time to take corrective action. This seems like en obvious way to address safety spaceras, which thould be the main intue.

\section{Refereaces}

1. N. A. Bakh, V. I. Medvedouskii, A. A. Reviaa, and V. D. Bityukov, Proc. Ist All-Union Conf. Radiation Chem. (Eaglish Treasl.), 39 (1957),

2. A. R. Kazanjian and D. R. Horrell, "Radiolytically Generated Gates in Plutonium-Nitric Acld Solutions," Radist. Effects 13, pD. 277.280 (1972).

3. N. E. Bibler, "Curłum-244 Alpha Radiolygis of Nitric Acld, Oxyren Production from Direet Redioiyste of Nitrate lons," J. Phys. Chem. 78(3) pp. 211.214 (1974),

4. J. C. Sheppard, "Alaha Radiolyais of Plutonium(IV)-Nitric Aeld Solutloas," Pacific Northweat Laboratory report BNWL-751 (May 1968).

5. Y. I. Savel'ov, Z. V. Ersbove, and M V. Vladimirove, "Alpha-Radiolysis of Aqueous Solutions of Nitric Acid," Radiokhim. 9(2) pp. 225.230 (1966). 


\section{Los Amom National Laboratory Safequard system scroup \\ N-4, Mail Stop:E-541/ 7-7777}

PAX COVER SHEET

To: Dr. Delbert R. Harbur NMT/DO

From: Dr. K K. S Pillay N-4, Mall Stop: $E-541$ LOSA Amosational Leboratory LOSAlamos,NM 87545 (USA).
FAX No. 7-7966

Verify

Fax (505)667-7026

Verify $(505), 667-5428$

\section{Message:}

Dear De! Harbur.

November 4, 1992

Yesterday evening Gordon Jarvinen of NMT-2 brought me a copy of the FAX message you received from Chuck Mason of Savannah River Field Office. Atthough Gordon was not clear as to what was expected of us, I read the package carefully and recognized the differences in the results of the twe studies by Bibler \& Shepperd. Also, I looked at some of the other literature on the subject and they all have somewhat different G-values for hydrogen evolution from nitrate media. I am not surprised at the difference considering the differences in experimerital conditions and the scavenging actions of other ionic species in the media. If the questions asked of you is to recommend actions to improve safety, my thoughts are as follows.

1. SRP should use Ned Bibler's conservative numbers on G-values for designing systems and in evaluating pressure spikes.

2. It would be prudent to install pd-based catalysts to remove hydrogen aceumulated in tanks routinely, especially when the purge system fail.

I talked with Fred Marsh this morning and we seem to generally agree on this.

Incidentally, there was a similar request from DOE/DP-62 to $N-6$ GroLip who consulted me on the subject. They also seem to agree with my suggestions as a reasonable answer to thie concerns raised.

If I can be further assistance, please let me hear from you.

\section{Regards.}

\section{SAM Pillay}

P. S.: I am looking forward to Joining NMT/Dn. soon. Rita Berry is thing find some office space for me.

Page 1 of 1. 

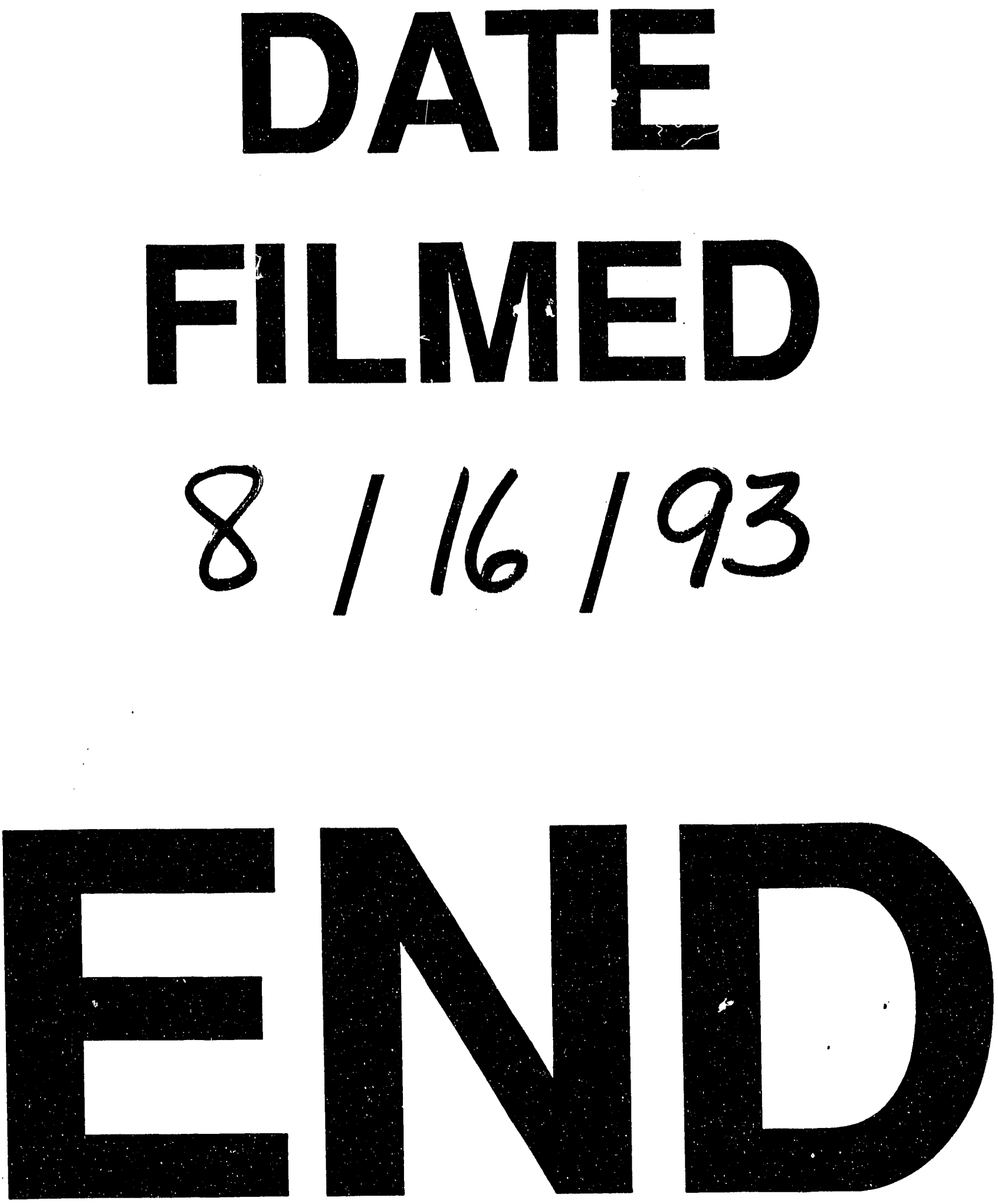
